\title{
Why inflation targeting central banks seem to follow a standard Taylor rule
}

Citation for published version (APA):

Kuehn, S., \& Muysken, J. (2009). Why inflation targeting central banks seem to follow a standard Taylor rule. METEOR, Maastricht University School of Business and Economics. METEOR Research Memorandum No. 058 https://doi.org/10.26481/umamet.2009058

Document status and date:

Published: 01/01/2009

DOI:

10.26481/umamet.2009058

Document Version:

Publisher's PDF, also known as Version of record

\section{Please check the document version of this publication:}

- A submitted manuscript is the version of the article upon submission and before peer-review. There can be important differences between the submitted version and the official published version of record.

People interested in the research are advised to contact the author for the final version of the publication, or visit the DOI to the publisher's website.

- The final author version and the galley proof are versions of the publication after peer review.

- The final published version features the final layout of the paper including the volume, issue and page numbers.

Link to publication

\footnotetext{
General rights rights.

- You may freely distribute the URL identifying the publication in the public portal. please follow below link for the End User Agreement:

www.umlib.nl/taverne-license

Take down policy

If you believe that this document breaches copyright please contact us at:

repository@maastrichtuniversity.nl

providing details and we will investigate your claim.
}

Copyright and moral rights for the publications made accessible in the public portal are retained by the authors and/or other copyright owners and it is a condition of accessing publications that users recognise and abide by the legal requirements associated with these

- Users may download and print one copy of any publication from the public portal for the purpose of private study or research.

- You may not further distribute the material or use it for any profit-making activity or commercial gain

If the publication is distributed under the terms of Article $25 \mathrm{fa}$ of the Dutch Copyright Act, indicated by the "Taverne" license above, 


\section{Maastricht University}

Stefan Kühn, Joan Muysken

Why inflation targeting central banks seem to follow a standard Taylor rule

$\mathrm{RM} / 09 / 058$

\section{METEOR}

Maastricht University School of Business and Economics

Maastricht Research School of Economics

of Technology and Organization

\section{P.O. Box 616}

NL - 6200 MD Maastricht

The Netherlands 


\title{
Why inflation targeting central banks seem to follow a standard Taylor rule*
}

\author{
Stefan Kühn ${ }^{\dagger} \quad$ Joan Muysken \\ November 12, 2009 \\ Department of Economics \\ Maastricht University \\ P.O. Box 616 \\ 6200 MD Maastricht
}

The Netherlands

WORKING PAPER

\begin{abstract}
Studies on central bank reaction functions find that central banks only caring about inflation stability, like the ECB, seem to follow a standard Taylor rule in the sense that the interest rate reacts significantly to variations in the output gap. We explain this result by claiming that the alleged reaction to the output gap could in fact be a reaction of the nominal interest rate to variations in the natural real rate of interest, which monetary policy should take into account. This provides a rationale for central banks to observe the output gap in the conduct of purely inflation targeting monetary policy.
\end{abstract}

JEL Classification: E58, O40

Keywords: New Keynesian Macroeconomics, Taylor Rule, Endogenous Growth

*We thank Bertrand Candelon, Julio Carillo, Lenard Lieb and Tom van Veen for valuable feedback.

†Corresponding Author. E-Mail address: s.kuehn@maastrichtuniversity.nl. Phone: +31433883653. Fax: +31433884150 


\section{Introduction}

Taylor (1993) found that interest rate setting by the FED seems to follow a remarkably simple rule of reacting to gaps in inflation and output relative to a target. Since then, many authors have estimated the Taylor rule for many countries. An interesting result is that a reaction of the nominal interest rate to deviations in the output gap is always found, even for central banks that allegedly only care for inflation, like the ECB (see for example Gorter and de Haan, 2008).

Woodford (2001) makes the point that theoretically a central bank interest rate rule consistent with inflation and output gap stabilisation requires knowledge about the Wicksellian natural real rate of interest (NRRI) as well as natural output. However, the major problem in the monetary policy literature is that the NRRI as well as natural output are unobservable. Furthermore, estimates of a time-varying NRRI suffer from an endogeneity problem and are imprecise when a non-model based approach is used (Laubach and Williams, 2003; Msonnier and Renne, 2007). Therefore, meeting the theoretical requirements for monetary policy as stated by Woodford (2001) encounters the huge problem of being infeasible due to unobservable required variables.

We argue, by utilising the co-movement between the NRRI and flexible price output, that employing a Taylor rule with a fixed intercept and trend output target meets the theoretical requirements by Woodford (2001). This simplifies the conduct of monetary policy significantly and can furthermore explain the finding that purely inflation targeting central banks also seem to put weight on the output gap. Equivalently, monetary policy should target output even if it only wants to stabilise inflation.

We show this in an $A K$ type endogenous growth model with endogenous labour supply and New Keynesian price stickiness. The use of the endogenous growth model allows a direct identification of the NRRI and its relation to the flexible price output, which drives the main result of our paper. In contrast, the normally used standard New Keynesian model does not allow a direct identification of the NRRI, even though Neiss and Nelson (2003) show that a similar relationship between the NRRI and flexible price output holds in a standard RBC model without capital adjustment cost. Therefore, the basic idea presented in this paper should also be applicable in the standard model.

Section 2 discusses the concept of the natural real rate of interest in the context of an endogenous growth model. In section 3 we show that not taking natural real rate fluctuations into account produces inflation instability. Section 4 derives Taylor rules with fixed intercepts that take variations in the natural real rate into account and thereby shows why inflation targeting central banks should target the output gap as well. 


\section{The Natural Real Rate of Interest}

Woodford (2003) defines the Wicksellian natural real rate of interest $r^{n}$ as the equilibrium real rate of interest that guarantees price stability. It is the real interest rate that aligns saving with investment and thereby demand with the flexible price level of output. Crucially, the NRRI is varying with exogenous demand and supply shocks (Woodford, $2003)$.

In an endogenous growth model the NRRI is the interest rate that aligns household savings with the investment required to generate the desired rate of growth. This implies that household's return on savings, given by the real interest rate $r$, has to equal the return on investment, which is the flexible price return on capital $r^{k^{f}}$ net of depreciation. ${ }^{1}$ Therefore, the natural real rate of interest is given by

$$
r^{n}=r=r^{k^{f}} .
$$

We derive the return to capital $r^{k}$ using a Romer (1986) type model where endogenous growth is generated by having constant returns to capital on aggregate, while each firm faces decreasing returns to capital.

The Cobb-Douglas production function for firm $i$ at time $t$ is

$$
Y_{i t}=A K_{i t}^{\alpha} L_{i t}^{1-\alpha} T F P_{t}^{1-\alpha}
$$

where $K$ and $L$ are capital and labour employed on the firm level, $\alpha$ is the marginal product of capital and TFP is labour augmenting technical progress. Endogenous growth is achieved by assuming $T F P_{t}=K_{t}{ }^{2}$ The aggregate production function normalised for capital is

$$
\frac{Y_{t}}{K_{t}}=A L_{t}^{1-\alpha}
$$

Firms minimise costs with respect to output. Interpreting the Lagrange multiplier of this minimisation as marginal costs $m c$, aggregate return to capital and labour, $r^{k}$ and $w$ respectively, are

$$
\begin{aligned}
r_{t}^{k} & =m c_{t} \alpha \frac{Y_{t}}{K_{t}}, \\
w_{t} & =m c_{t}(1-\alpha) \frac{Y_{t}}{L_{t}} .
\end{aligned}
$$

Marginal costs are constant under flexible prices and equal the inverse of the gross markup $(\mu)$, which firms can set in monopolistic competition facing a downward sloping demand curve (see e.g. Woodford, 2003). Like basic New Keynesian models, we

\footnotetext{
${ }^{1}$ For clarity of exposition, we assume no depreciation.

${ }^{2}$ Romer (1986) argues that TFP is a function of $K$ with $T F P^{\prime}(K)=1$. Setting TFP $=\mathrm{K}$ is used for ease of notation.
} 
assume endogenous labour supply which increases with the real wage adjusted for TFP $\left(L^{\prime}\left(\frac{w}{K}\right)>0\right)$. Turnovsky (2000) shows that labour supply will be constant in the steady state.

The equilibrium return to capital under flexible prices is

$$
r_{t}^{k^{f}}=\frac{\alpha}{\mu}\left(\frac{Y_{t}}{K_{t}}\right)^{n}
$$

From the discussion above, it follows that equation 4 represents the natural real rate

of interest in an endogenous growth model, where $\left(\frac{Y_{t}}{K_{t}}\right)^{n}$ is the natural (flexible) price output capital ratio. When return to capital $r_{t}^{k}$ differs from the NRRI, marginal costs are not at their flexible price level.

\section{Monetary Policy}

As Woodford (2003) noted, changes in the NRRI have to be mirrored by changes in the actual real rate to maintain price stability. Under flexible prices, a model without a central bank automatically reaches that equilibrium through adjustments on the bond market, and thus via the nominal interest rate, without effects on the inflation rate $\pi$.

Monetary policy and an interest rule only make sense in a sticky price model like Calvo (1983) staggered price setting. Sticky prices cause deviations in real wages from their flexible price level, which lead to deviations of marginal costs as well as labour supply and thus output from their flexible price level. Furthermore, inflation increases when marginal costs rise above their flexible price level. Inflation stability requires that the real interest rate equals the NRRI, otherwise marginal costs are not at their flexible price level and induce a change in inflation.

Arbitrage ensures that the return to capital $r^{k}$ equals the real interest rate on other assets like bonds. The Fisher equation

$$
r_{t}=i_{t}-\pi_{t}^{e}
$$

relates the real interest rate to the nominal interest $i$ rate and expected inflation $\pi^{e}$. Assuming rational expectations, inflation stability requires that the nominal interest rate minus the desired inflation equals the NRRI at all times. Therefore, changes in the NRRI have to be matched by changes in the nominal interest rate. Otherwise, inflation will react and lead to an adjustment.

If monetary policy were to follow an interest rate rule that only reacts to inflation deviations, a rise in the NRRI following a supply shock will initially not be accommodated by a rise in the nominal interest rate. There is a disequilibrium on the financial markets, where capital earns a higher return than bonds $\left(r^{k}>r\right)$. Firms now face a cost of 
borrowing lower than their return on investment, which lowers their cost of capital. Due to their optimality condition (the ratio of equations $3 \mathrm{a}$ and $3 \mathrm{~b}$ ), firms are required to lower labour costs by lowering real wages and labour demand. This leads to lower labour supply and output.

Furthermore, lower capital and labour costs lower marginal costs, which lowers inflation. As shown by Dupor (2001), determinacy, implying the equalisation of returns $\left(r^{k}=r=i-\pi\right)$, requires a passive interest response to inflation by the central bank so that the real interest rate rises as inflation falls. ${ }^{3}$ Hence, the rise in the NRRI is accommodated by a fall in actual return to capital and a rise in the central bank real interest rate.

This analysis shows that the point made by Woodford (2003), which requires the central bank to react to changes in the NRRI to stabilise inflation, also holds for endogenous growth models.

\section{The Taylor Rule}

The monetary policy rule followed by the FED was estimated by Taylor (1993) as

$$
i_{t}=0.04+1.5\left(\pi_{t}-0.02\right)+0.5\left(y_{t}-\bar{y}_{t}\right)
$$

where $y_{t}-\bar{y}_{t}$ is the output gap. Woodford (2001) argues that such a Taylor rule can be obtained by minimising a central bank loss function of output and inflation. He noted that $\bar{y}_{t}$ should be replaced by the natural output and the intercept, representing the NRRI, should also take into account changes in this rate. The Taylor rule should therefore be specified as

$$
i_{t}=r_{t}^{n}+\bar{\pi}+\rho_{\pi}\left(\pi_{t}-\bar{\pi}\right)+\rho_{y}\left(y_{t}-y_{t}^{n}\right),
$$

where $\bar{\pi}$ represents the target for inflation and $y^{n}$ natural output. Such a policy requires a correct estimation of the current flexible price output as well as the NRRI.

Using the definition of the NRRI, equation (4), we obtain

$$
i_{t}=\frac{\alpha}{\mu}\left(\frac{Y_{t}}{K_{t}}\right)^{n}+\bar{\pi}+\rho_{\pi}\left(\pi_{t}-\bar{\pi}\right)+\rho_{y}\left(y_{t}-y_{t}^{n}\right)
$$

Since the capital stock is predetermined, the output gap approximations

$$
\frac{Y_{t}}{K_{t}}-\overline{\left(\frac{Y}{K}\right)}=y_{t}-\bar{y} \text { and } \frac{Y_{t}}{K_{t}}-\left(\frac{Y_{t}}{K_{t}}\right)^{n}=y_{t}-y_{t}^{n},
$$

\footnotetext{
${ }^{3}$ An active interest response raises the nominal interest rate by more than one for one with inflation, a passive interest response by less. Dupor (2001) shows that this result holds for all models with capital accumulation.
} 
where $\overline{\left(\frac{Y}{K}\right)}$ is an estimate of the steady state output capital ratio, are reasonable.

Equation 7 can then be rewritten to

$$
i_{t}=i^{*}+\rho_{\pi}\left(\pi_{t}-\bar{\pi}\right)+\rho_{y}^{*}\left(y_{t}-\bar{y}\right)
$$

with

$$
\begin{aligned}
\rho_{y}^{*} & =\frac{\alpha}{\mu}, \\
i^{*} & =\frac{\alpha}{\mu} \overline{\left(\frac{Y}{K}\right)}+\bar{\pi},
\end{aligned}
$$

where $i^{*}$ is the nominal target interest rate corresponding to the steady state NRRI and we impose $\rho_{y}=\rho_{y}^{*}$. Equation (8) is equivalent to the original Taylor rule (5) and proves that the use of a fixed intercept and output target in the Taylor rule is equivalent to the use of a flexible NRRI and a flexible price output target. This is supported by Giammarioli and Valla (2003), who find using a standard New Keynesian model that "accounting for the fluctuations of $r^{*}$ over time only slightly improves the stability of the economy, mostly through a better stabilisation of the output gap."

A central bank reaction function where only inflation stabilisation is part of the objective function should have the form

$$
i_{t}=r_{t}^{n}+\bar{\pi}+\rho_{\pi}\left(\pi_{t}-\bar{\pi}\right)
$$

Using the notation from above, this can be rewritten to

$$
i_{t}=i^{*}+\rho_{\pi}^{\prime}\left(\pi_{t}-\bar{\pi}\right)+\rho_{y}^{*}\left(y_{t}-\bar{y}\right)
$$

with

$$
\rho_{\pi}^{\prime}=\rho_{\pi}-\rho_{y}^{*} \frac{\left(y_{t}-y_{t}^{n}\right)}{\pi_{t}-\bar{\pi}} .
$$

Since $\frac{\left(y_{t}-y_{t}^{n}\right)}{\pi_{t}-\bar{\pi}}>0^{4}, \rho_{\pi}^{\prime}$ is adjusted downward to account for the central bank reaction to the inflation inducing part of the output gap already embedded in the $\rho_{y}$-part of equation 10 . The size of the adjustment is in principle unknown but could be approximated with the response of inflation to the output gap, which is assumed to be stable over time.

A central bank only caring for inflation stability should use the policy rule equation 9 . However, this requires timely information on the NRRI, which might not be available.

${ }^{4}$ The ratio of actual to flexible price output is

$$
\frac{Y_{t}}{K_{t}} /\left(\frac{Y_{t}}{K_{t}}\right)^{n}=\left(\mu m c_{t}\right)^{1-\alpha}
$$

Higher marginal costs, as they occur when $y_{t}>y_{t}^{n}$, induce inflation. 
Our analysis shows that the conventional Taylor rule, which uses a constant intercept, takes these fluctuations in the natural real rate of interest into account (see equation 10). Therefore, even central banks which supposedly only care about inflation will act in line with the standard Taylor rule - that is take the output gap into account when setting the interest rate. This might explain why many studies (e.g. Gorter and de Haan, 2008) also find that the ECB follows the standard Taylor rule.

Furthermore, we highlight the importance for central banks to take the output gap into account when setting monetary policy due to the difficulty of obtaining a direct reliable measure of the NRRI. Finally, the unavailability of measures of the NRRI and natural output are not problematic for central banks following a standard Taylor rule with fixed intercept and output target, as such a Taylor rule takes these fluctuations into account.

\section{References}

Calvo, G. A., 1983, Staggered prices in a utility-maximizing framework, Journal of Monetary Economics 12, 383-398.

Dupor, B., 2001, Investment and interest rate policy, Journal of Economic Theory 98, $85-113$.

Giammarioli, N. and N. Valla, 2003, The natural real rate of interest in the EURO area, ECB working paper series (233).

Gorter, J. and J. de Haan, 2008, Taylor rules for the ECB using expectations data, Scandinavian Journal of Economics 110(3), 473-488.

Laubach, T. and J. C. Williams, 2003,), Measuring the natural rate of interest, The Review of Economics and Statistics 85(4), 1063-1070.

Msonnier, J.-S. and J.-P. Renne, 2007, A time-varying "natural" rate of interest for the euro area, European Economic Review 51, 1768-1784.

Neiss, K. S. and E. Nelson, 2003, The real interest rate gap as an inflation predictor, Macroeconomic Dynamics 7, 239-262.

Romer, P., 1986, Increasing returns and long-run growth, Journal of Political Economy 94(5), 1002-1037.

Taylor, J. B., 1993, Discretion verus policy rules in practice, Carnegie-Rochester Conference Series on Public Policy 39, 195-214. 
Turnovsky, S. J., 2000, Fiscal policy, elastic labour supply and endogenous growth, Journal of Monetary Economics 45, 185-210.

Woodford, M., 2001, The Taylor rule and optimal monetary policy, The American Economic Review 91(2), 232-237.

Woodford, M., 2003, Interest and Prices, Princeton University Press. 